\title{
Basement Characteristics of Jakarta Groundwater Basin Based On Satellite Gravimetry Data
}

\author{
Gumilar Utamas Nugraha, Lina Handayani, Rachmat Fajar Lubis, Dadan Dani Wardhana and Karit \\ Lumban Gaol \\ Research Center For Geotechnology, Indonesian Institute of Sciences, Indonesia.
}

Received: 2019-07-07

Accepted: 2020-03-03

Key words: Gravimetry Data;

Groundwater Basement;

Jakarta Groundwater Basin.

Correspondent email:

gumi001@lipi.go.id

\begin{abstract}
Jakarta groundwater basin is one of the most developed basins in Indonesia as Jakarta city is located within the basin, with an elevation ranging from 0 to $1000 \mathrm{~m}$ above sea level. The study of the basement characteristics of groundwater basins still needs further study in the Jakarta Groundwater Basin. The objective of this study is to examine the basement characteristics of Jakarta Groundwater Basin by satellite gravimetry. Gravity forward models were constructed using Oasis Montaj and 2-D GM-SYS software for two north-south sections, A and B, and west-east section C-D. Regional anomalies in the study area with a value range of 36.7 to $53.2 \mathrm{mGal}$, while the residual anomaly values in the study area were in the range of 7.0 - $10.0 \mathrm{mGal}$. There are four rock formations based on forwarding modeling. Holocene Beach Ridge Deposit formation has a density of $2.0 \mathrm{gr} / \mathrm{cc}$. The thickness of this formation is estimated to be around 10-20 meters. Late Pleistocene Alluvial fan has a density of about $2.2 \mathrm{gr} / \mathrm{cc}$. The depth of this layer ranges from 1050 meters. Early Pleistocene Formation, has a density of $2.35 \mathrm{gr} / \mathrm{cc}$. The thickness of this formation is at a depth of 50-200 meters in the cross-section. The Tertiary Marine Sediment Formation is a basement of the Jakarta Groundwater Basin. This formation has a rock density of $2.45 \mathrm{gr} / \mathrm{cc}$.
\end{abstract}

๑ 2020 by the authors. Licensee Indonesian Journal of Geography, Indonesia

This article is an open access article distributed under the terms and conditions of the Creative Commons

Attribution(CC BY NC) licensehttps://creativecommons.org/licenses/by-nc/4.0/.

\section{Introduction}

Jakarta groundwater basin is one of the most developed basins in Indonesia as Jakarta city is located within the basin, with an elevation ranging from 0 to $1000 \mathrm{~m}$ above sea level (Lubis et al., 2009). According to Delinom et al. (2015) laterally, the Jakarta groundwater basin is bordered by the geological structure. In the hydrogeological analysis, geological formations can act as a channel or as a barrier to groundwater. In the Jakarta groundwater basin, indicating that the fault structure has a role as a groundwater channel because of the direction of faults, which are generally in line with the groundwater movement. In the western part, this basin is bordered by the Cidurian fault, while in the southern part of this basin is bordered by the Bogor anticlinorium line. In the east and north, the boundary of this basin must still be studied further. It is estimated, in the eastern part, this basin is bordered by a normal fault associated with Rengasdengklok uplift, whereas in the north, it is estimated that stratigraphic facies changes border the distribution of aquifer systems in this basin. The characteristics of the basin basement are fundamental in the planning and development of a region, especially for analyzing the capacity of the environment and natural resources. The study of the basement characteristics of groundwater basins still needs further research in the Jakarta Groundwater Basin. Importantly, study the features of the basement of the groundwater basin estimation of groundwater availability in the quarter sediment that fills in the basement of the groundwater basin.

The gravity method is still the best choice for basin study (Kirsch, 2009). Murty and Raghayan (2002) use the gravity method in groundwater exploration in hard granite rock environments. In their research, the remaining anomalous data on gravity can be used to distinguish igneous rocks that have undergone weathering and those that do not, help attract straightness of fault structures, and identify layers that have potential as aquifers (Handayani et al., 2017). Chandler (1994) uses it in mapping the thickness and potential of groundwater in a sedimentary rock environment. Carmichael and Henry (1977) conducted a groundwater exploration in glacier areas. They can map the location of valleys buried beneath the surface and generally map the bedrock surface for an inventory of groundwater sources (Handayani et al., 2017). Also, several other studies use a combination of gravity methods with other geophysical methods, such as Santos et al., (2006) and Overmeeren (1981). The overall re- 
search that has been conducted shows that the gravity method is an effective method for regional scales in groundwater exploration (Handayani et al., 2017).

The method of determining the gravity field and geoid using missions from the Gravimetric Satellite began to be developed at this time. The purpose of the Gravimetric Satellite includes GRACE (Gravity Recovery and Climatology Experiment) and GOCE (Gravity field and steady-state Ocean Circulation Explorer). For this study, we used Free-air gravity anomaly V27.1 from Sandwell et al. (2014) that combined data from CryoSat-2, The Envisat satellite, and The Jason-1 satellite.

We apply the gravity method in groundwater basin studies in the Jakarta Groundwater Basin. Bouguer gravity anomaly mapping and its derivatives can describe regional subsurface conditions, especially basement configurations and main structural structures that can directly affect the distribution of aquifer layers. The purpose of this study was to examine Basement Characteristics of Jakarta Groundwater Basin Based On Satellite Gravimetry Data.

Jakarta lies on the lowlands of the northern coast of West Java province in Indonesia, and it has been one of the Asian megacities from the early 2000s (Saito et al., 2011). The overall population of Jakarta increased significantly in the 20th century, from about 100,000 in 1900 to more than 9 million in 1995. Most of the population increase occurred in the last 20 years of the 20th century (Han and Basuki, 2001). The current population is approximately 12 million (Saito et al., 2011).

According to Engelen and Kloosterman (1996), as cited in Delinom et al. (2008), structurally, the Jakarta Basin is part of the so-called Northern Zone comprising the low hilly areas of folded Tertiary strata, and coastal lowlands bordering the Java Sea. Regionally, Jakarta Area is occupied by a lowland area that has five main landforms (Rimbaman and Suparan, 1999, as cited in Delinom et al., 2008) that consists of:

1. volcanic and alluvial landforms that are found in the southern part of the basin;

2. marine origin landforms, which are occupied the northern area adjacent to the coastline;

3. beach ridge landforms, which are discovered along the coast with east-west direction;

4. swamp and mangrove area landforms, which are encountered in the coastal fringe;

5. paleo-channels, which run perpendicular to the coastline.

Geologically, the study area is dominated by quaternary sediment, and, unconformably, the base of the basin is formed by impermeable Miocene limestone sediments cropping out at the southern region, which were known as Bojongmanik and Klapanunggal Formation (Delinom et al., 2008). The basin fill, which consists of marine Pliocene and quaternary sand and delta sediments, is up to $300 \mathrm{~m}$ thick (Delinom et al., 2008). Individual sand horizons are typically 1-5 m thick and comprise only $20 \%$ of the total fill deposits. Silts and clays separate these horizons. Fine sand and silt are widespread components of these aquifers (Martodjodjo, 1984; Asseggaf, 1998), and the sand layers were connected (Fachri et al., 2003).

The base of the aquifer system is formed by impermeable Miocene sediments, which also outcrop at the southern boundary of the basin (Djaja et al., 2004). The basin fill consists of marine Pliocene and Quaternary sand and delta sediments up to $300 \mathrm{~m}$ thick. Quaternary deposits may be conveniently divided into three aquifer systems based on hydraulic characteristics and depth: the Phreatic Aquifer System $(0$ to $40 \mathrm{~m})$, the Upper Confined Aquifer System (-40 to $-140 \mathrm{~m}$ ), and the Lower Confined Aquifer System (deeper than $-140 \mathrm{~m}$ ). Around the Jakarta metropolitan area, the average horizontal hydraulic conductivity is approx. $1.0 \times 10$ $\mathrm{cm} / \mathrm{s}$, and the vertical value about $1.0 \times 10-3 \mathrm{~cm} / \mathrm{s}$, respectively. (Saito et al., 2011)

The Jakarta groundwater basin, in which the city of Jakarta resides, is one of the most developed basins in Indonesia. The aquifer system in this basin is classified (upper to lower order) into the following five zones (Fachri et al., 2003):

- Zone 1 is a shallow aquifer layer composed of sandstone, conglomerate, and claystone;

- Zones 2 and 4 are aquiclude layers formed of claystone with sand infixes;

- Zone 3 is a deep aquifer layer composed of sandstone with infixes of breccias and claystone;

- Zone 5 is the basement of the Jakarta groundwater basin, consisting of impermeable rocks such as limestone and claystone.

The components of the aquifer, such as sandstone and conglomerate, are connected (Martodjodjo, 1984; Asseggaf, 1998). The deep aquifer under the urban area is about $150-\mathrm{m}$

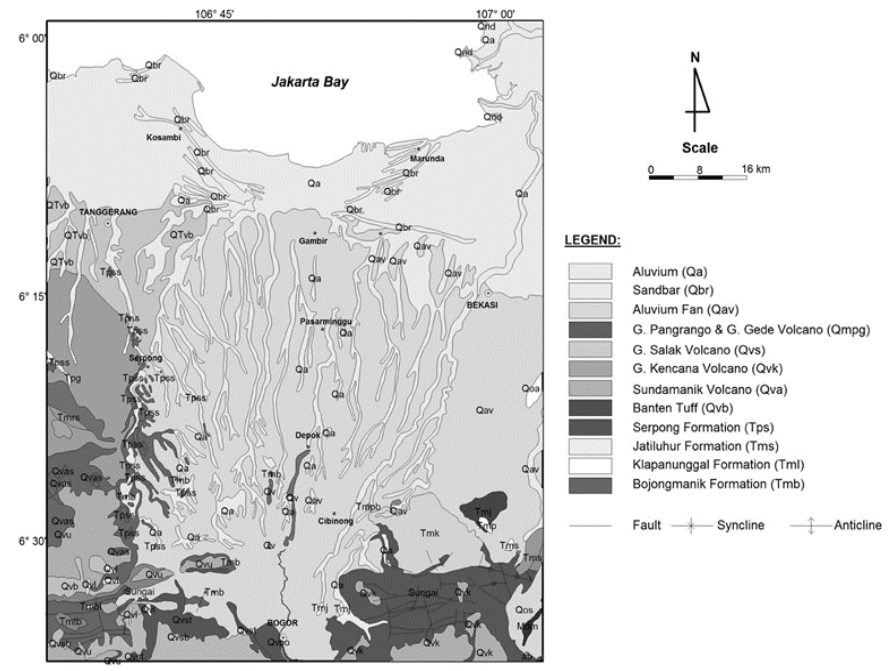

Figure 1. Geology of Study Area (Effendi, 1974; Sudjatmiko, 1972; Turkandi et al., 1992, Delinom et al.,2008) 
thick. The vertical cross-section of the local hydrogeology along the line (A-A') in Figure. 1a (south to north) is shown in Figure. 6, Figure. 10. In this paper, we classified the groundwater samples collected from the wells into five zones based on screen existing elevation.

Lubis (2017) comprise the Jakarta groundwater basin-fill, which consists of marine Pliocene and Quaternary sand and delta sediments up to $300 \mathrm{~m}$ thick. Based on groundwater monitored data of 51 monitoring wells around Jakarta area, it can be concluded that most of water level in Jakarta area of 5 clusters aquifers, i.e., 0- 40 meters, 40 - 95 meters, 95 - 140 meters, 140 - 190 meters, and 190 - 250 meters (Delinom, 2008). Another has divided eight groups of aquifer systems, forming an unconfined system $(0-20 \mathrm{~m})$ and 7 confined groundwater aquifers $(20-300 \mathrm{~m})$ (Lubis, 2017). The latest study that was conducted, focusing on the distribution of aquifer systems and aquitards in the Jakarta groundwater basin by hydrostratigraphy approach. This concept resulted in two groups of the aquifer system and aquitard system with basin base of Tertiary age sedimentary rock. The study

(a)

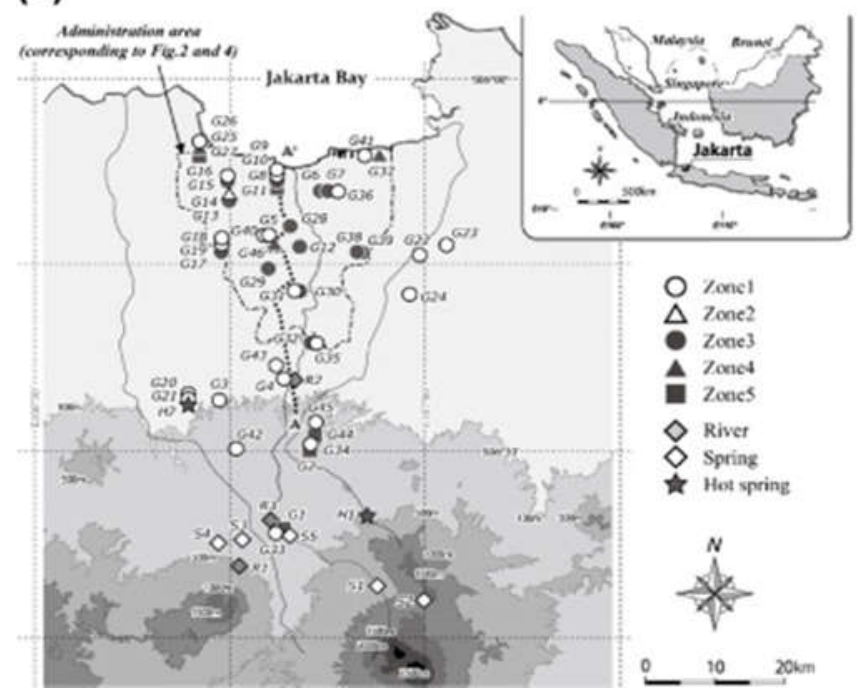

Figure 2. Jakarta Groundwater Basin, Kagabu, et al. (2010)

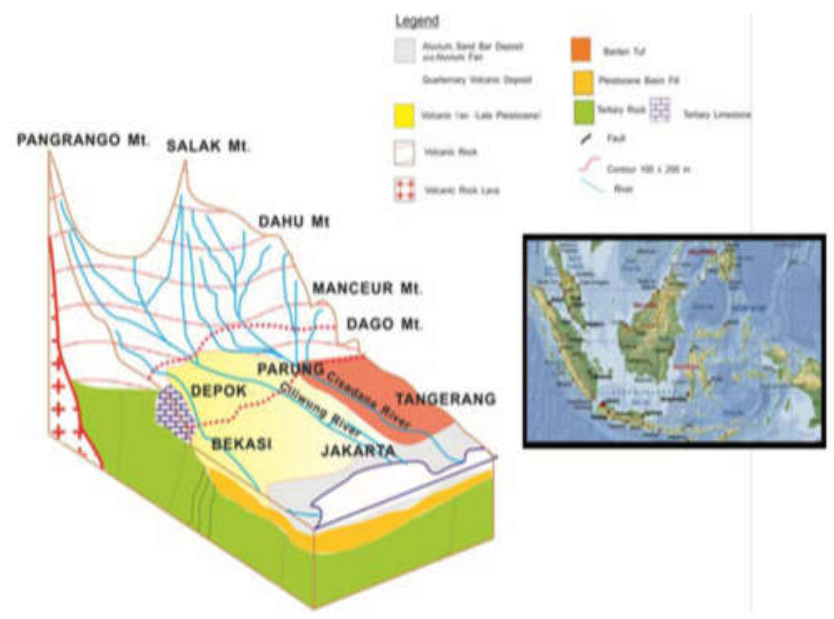

Figure 3. Jakarta city which lays in Jakarta Groundwater basin (Turkandi et al., 1992 as cited in Lubis, 2017) area covered the groundwater basin, including the metropolitan area of Jakarta.

\section{The Methods}

High-resolution satellite-derived Free Air Gravity (FAG) data (V.24.1, Sandwell and Smith, 2009; Sandwell al., 2014) generated from re-tracked Seasat, Geosat GM, TOPEX/ POSEIDON, ERS-1/2, Cryosat-2 and Jason-1 altimeter data (ftp://topex.ucsd.edu/pub/global_grav_1min/) and bathymetry data (V.18.1, Smith and Sandwell, 1997) derived from satellite altimetry, each having a resolution of one arc minute is used in the present study for the regional data analysis (Figure 6. Free Air Anomaly Gravity Datum Point (Kunnummal et al., 2018). Bouguer anomaly maps were obtained applying statistical gridding according to the mini-

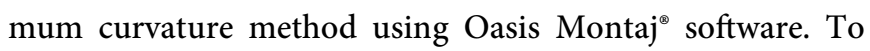
separate long-deep and short-shallow wavelength potential field anomalies, the cutoff wavelengths and information about the contribution of the short and long wavelengths in the spectrum can be obtained from the calculated radiallyaveraged power spectrum of the data using fast Fourier transform (FFT) (Spector and Grant, 1970; Bhattacharya, 1965). Spectral analysis of the potential field anomalies indicates an average ensemble depth to different sources of

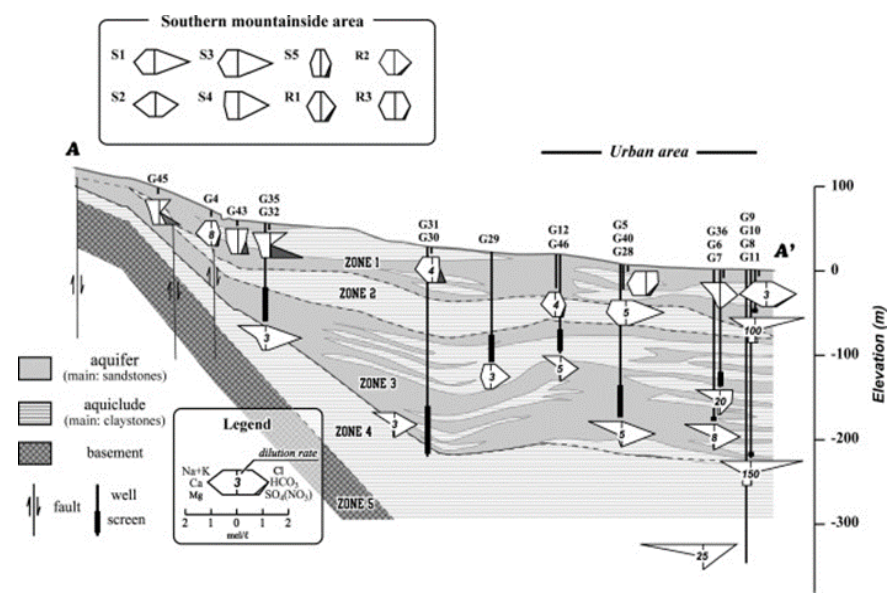

Figure 4. Vertical distribution of the stiff diagram along a cross-section shown in Figure. 1 (Kagabu et al., 2010)

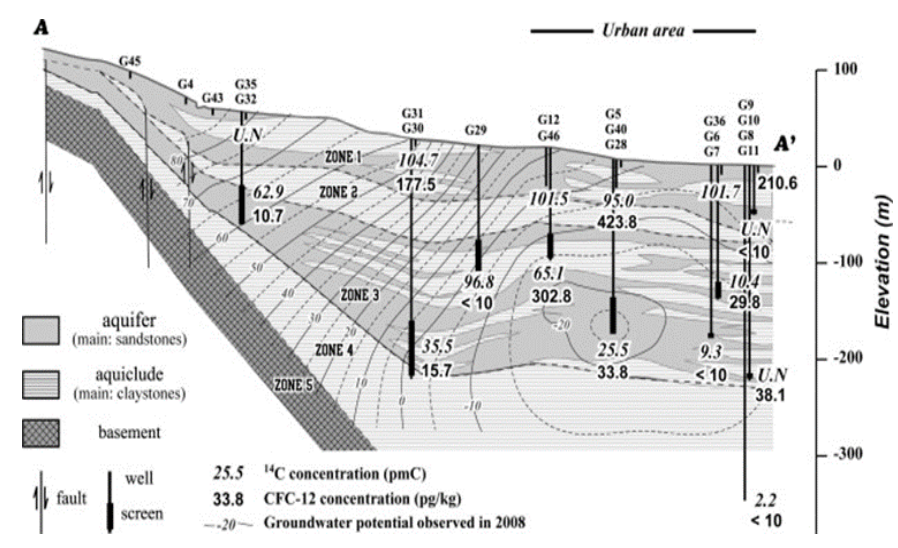

Figure 5. Vertical distribution of ${ }^{14} \mathrm{C}$ and CFC-12 concentrations along a cross-section shown in Figure. 1

(Kagabu et al., 2010) 
anomalies (Reeves, 2005; Rama Rao et al., 2011; Whitenhead and Musselman, 2011). The power spectrum of the gravity fields for the Jakarta area can be approximated by two linear segments (Figure. 5a and c). The low-frequency segment relates to deeper sources, and the high-frequency section relates to shallower sources. This methodology averages source depths over a region containing complex anomalies and is less affected by interference due to overlapping anomalies and high-frequency noise than other methods The Bouguer anomaly map contains two effects; one regional (attributed to the lower crust and mantle) and another residual (attributed to the upper crust and intra-basement gravity sources). The regional-residual separation was obtained using Butterworth filters to a height of $10 \mathrm{~km}$. Topographical and gravimetric profiles were made on the Bouguer residual map. A density of $2.67 \mathrm{~g} / \mathrm{cm} 3$ was considered for the upper crust rocks, according to the proposal by Hinze (2003). The Gaussian filter tool is applied in the frequency domain using different parameters through the Geosoft Oasis Montaj software version 6.4.2. For every station, the complete Bouguer anomaly through Free Air $(\mathrm{FAC}=0.3086 \mathrm{~h})$, Bouguer $(\mathrm{BC}=0.11118 \mathrm{~h})$, and Topography/terrain corrections were calculated, where $\mathrm{h}$ is the height of the station in meters concerning to the mean sea level. Terrain corrections were computed according to the algorithms developed by Kane (1962) and Nagy (1966); considering a local elevation model $(1 \mathrm{~km} \times 1 \mathrm{~km})$ and a regional elevation model $(10 \mathrm{~km} \times 10 \mathrm{~km})$; both elevation models were obtained from the Global elevation model ETOPO 1. Gravity forward models were constructed using Oasis Montaj and 2-D GM-SYS software for two north-south geological sections, A and B, across northern and Southern part zone.

\section{Result and Discussion}

The gridding of free air anomaly gravity using the (Oasis Montaj software )with a minimum curvature method showed that the open air anomaly gravity values in the Ja-

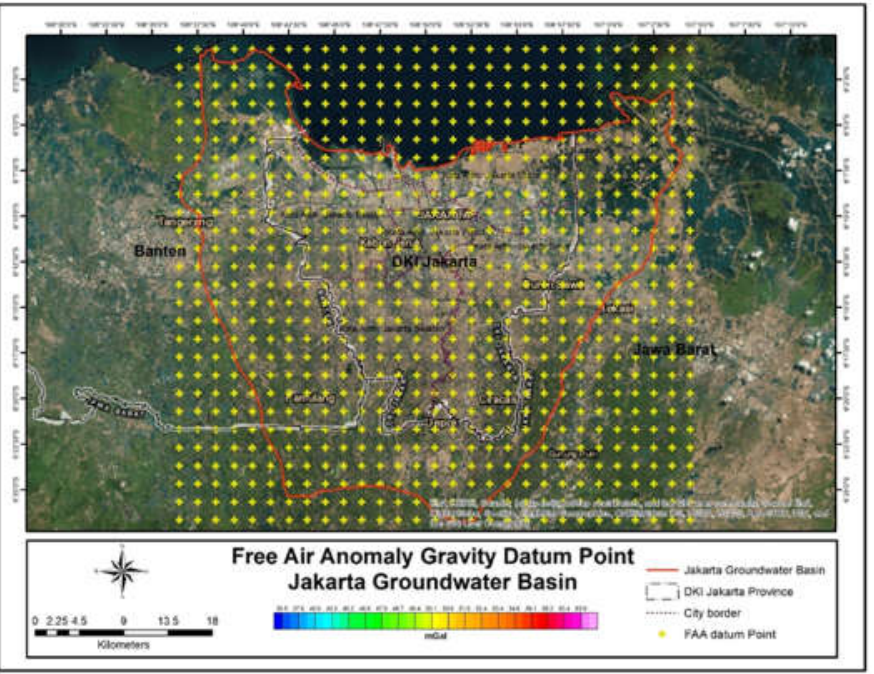

Figure 6. Free Air Anomaly Gravity Datum Point karta Groundwater Basin in the range of 33.5 - $63.9 \mathrm{mGal}$. There are three anomaly zones in the study area: the low anomaly zone, medium anomaly zone, and high anomaly zone (Figure 7. Free Air Anomaly Maps). Low anomaly zone relatively located in the eastern region of the study area with a value of anomaly 33.5 - $45.2 \mathrm{mGal}$. The low anomaly zone is located on the right side of the map (east), which extends from the Northeast towards the Southwest Jakarta Groundwater basin. The medium anomaly zone is located in the central part of the Jakarta Groundwater Basin with value 45.2 $51.6 \mathrm{mGal}$. Medium anomaly zones generally separate high Anomaly zones and low anomaly zones. The high anomaly zone located in the northern part and southern part of the Jakarta Groundwater Basin, this zone has a value range of 51.6 - $63.9 \mathrm{mGal}$. In the northern part, it stretches from the eastern to the western part of Jakarta Groundwater Basin. In the southern part, the high anomaly zone extends from the eastern to the western part of Jakarta groundwater basin. The analysis continued with Bouguer and terrain correction on the available data.

The value of complete Bouguer anomaly in Jakarta Groundwater Basin is obtained. After Bouguer and terrain correction is calculated (Figure. 8). Gridding results using (Oasis Montaj software) with the minimum curvature gridding method show different values from the previous free air anomaly gravity data, the range of values in complete Bouguer anomaly is in the range of $30.9-62.0 \mathrm{mGal}$ (Figure 9). The low anomaly zone is in the range of $30.9-42.1 \mathrm{mGal}$, this zone is located in the eastern region of the study area. This anomaly extends from the Northeastern to the Southwestern part of Jakarta Groundwater Basin. Unlike the previous free air anomaly gravity map, this zone elongated on the right side of the map towards the southwest part direction. The existence of this zone tends to dominate in the eastern part of the map, even though it can identify in the middle part of the map. The medium anomaly zone is in the range 42.1 - $48.9 \mathrm{mGal}$ (Figure 9). In the previous free air anomaly

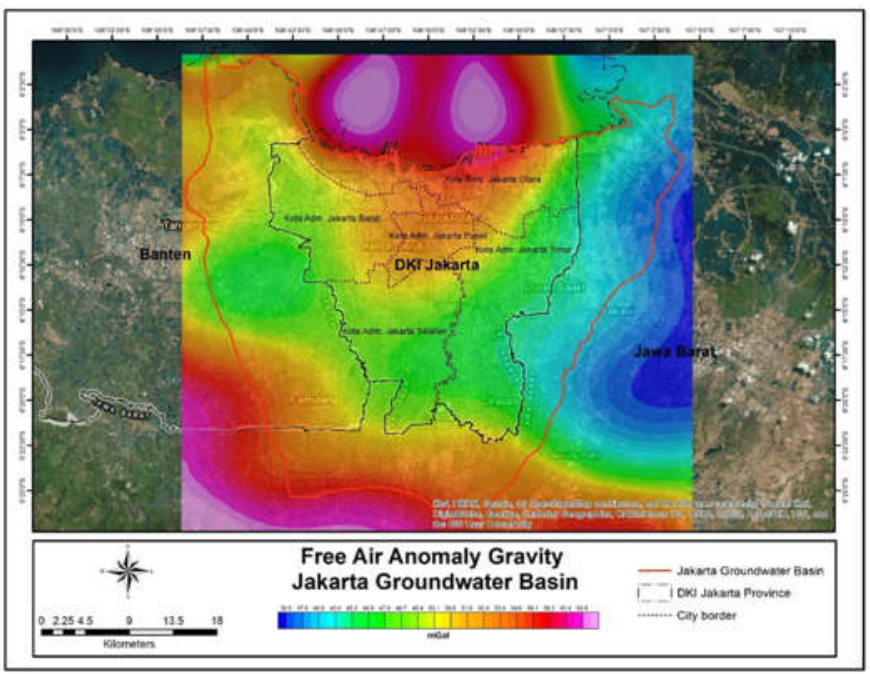

Figure 7. Free Air Anomaly Maps 
gravity map, the anomaly zone was in the central part of the Jakarta Groundwater Basin, but the complete Bouguer anomaly map of the Jakarta Groundwater Basin zone tended to expand towards the southern part of the study area due to the presence of high anomaly zones in the northern part of the Jakarta groundwater basin. This medium anomaly zone separates areas with high and low anomaly zones on the map of Complete Bouguer Anomaly. On the Complete Bouguer Anomaly map, the high anomaly zone is in the range of 48.9 - $62.0 \mathrm{mGal}$ (Figure 9). This zone is located northern part of the Jakarta Groundwater Basin. Almost along the coast is a high anomaly zone. This zone continues to the center part of the Jakarta Groundwater Basin. Unlike the previous free air anomaly map, where the existence of this zone tends to disappear in the southern part of the Jakarta Groundwater Basin. This high zone is dominant in the northern part of the Jakarta Groundwater Basin and continues to the west. Complete Bouguer is an accumulated value of residual anomalies and regional anomalies. Therefore it is necessary to separate regional anomalies and residual anomalies to obtain subsurface conditions from the Jakarta Groundwater basin.

There are six cross-sections line for spectral analysis (Figure 10.Six locations of cross-section lines of Bouguer gravity anomalies for Spectral Analysis ), consisting of three lines with north-south direction and three lines with westeast direction. The names of each line are lines $1,2,3,4,5$, and 6 . The distribution of the cross-section line is considered enough to present the conditions in the study area.

Fourier transform converts a signal into a sum of several sinusoidal signals with various frequencies. Analysis of the spectrum of Fourier transform results from each data slicing anomaly gravity is described as a scatter diagram between wavenumber (k) and amplitude (A). The cutoff $k$ value is the intersection of regional and residual linear functions used to determine the filter window width in the process of separating the gravity anomaly value. The relationship between amplitude $\mathrm{A}$ and wave number $\mathrm{k}$ is a linear relationship with a

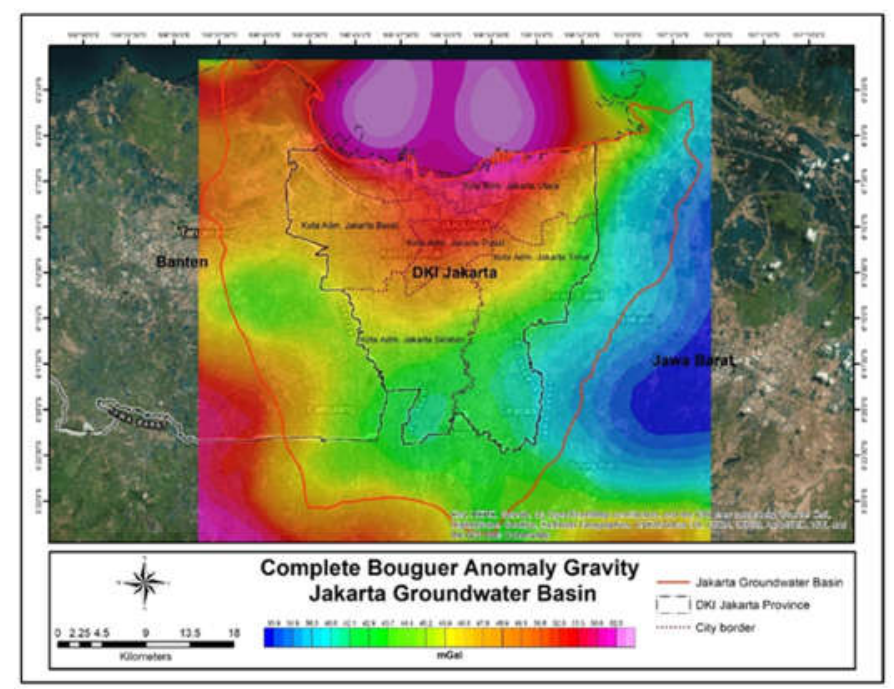

Figure 8. Complete Bouguer Anomaly Maps different gradient which is indicated by a straight line equation in the regional spectrum area (blue dots), residuals (brown dots) and noise (gray dots) ) There are intersections of lines at the regional-residual anomaly boundaries and residuals that will produce a cutoff wave number ( $\mathrm{k}$ cutoff). The results of spectrum analysis (Figure 11. Spectral Analysis Result) were observed on six tracks, namely line 1 , line 2 , and line 3 in the west - east direction, while line 4, line 5, and line 6 in the north - south direction.

Table 1 shows the depth of regional and residual anomalous responses. The unusual response in each line in the residual anomaly is sufficiently variated. Line 1 shows the residual anomaly response at a depth of $-595.09 \mathrm{~m}$; Line 2 shows a residual anomaly response at a depth of $-592.03 \mathrm{~m}$, Line 3 shows a residual anomaly response at a depth of $286.50 \mathrm{~m}$. Line 4 shows the residual anomaly response at a depth of $-524.22 \mathrm{~m}$, Line 5 shows the residual anomaly response at a depth of $-489.45 \mathrm{~m}$, and Line 6 shows a residual anomaly response at a depth of $-477.71 \mathrm{~m}$. Regional anomaly

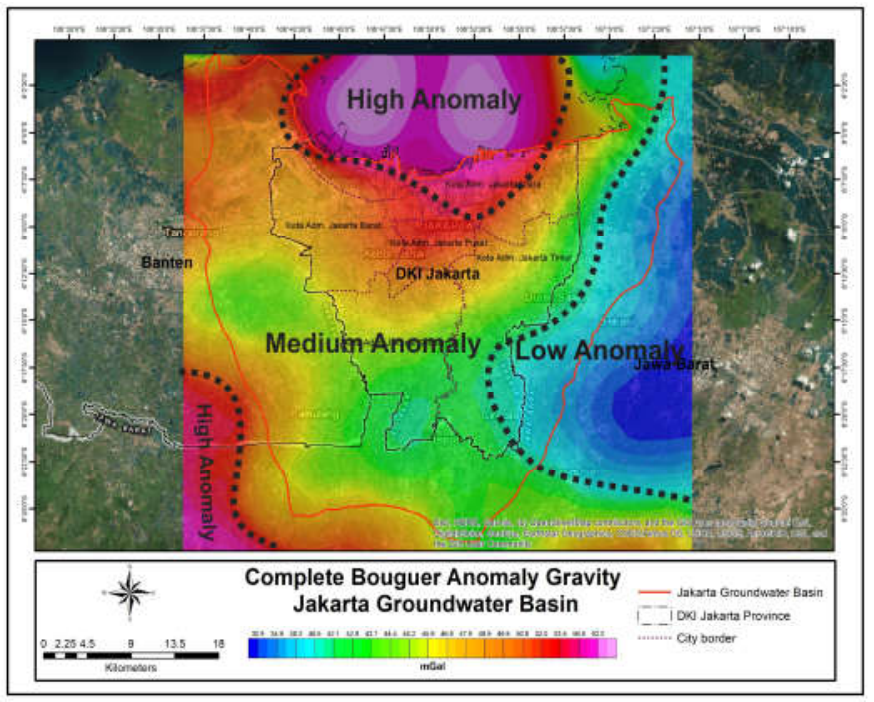

Figure 9. Complete Bouguer Anomaly classification in Jakarta Groundwater Basin

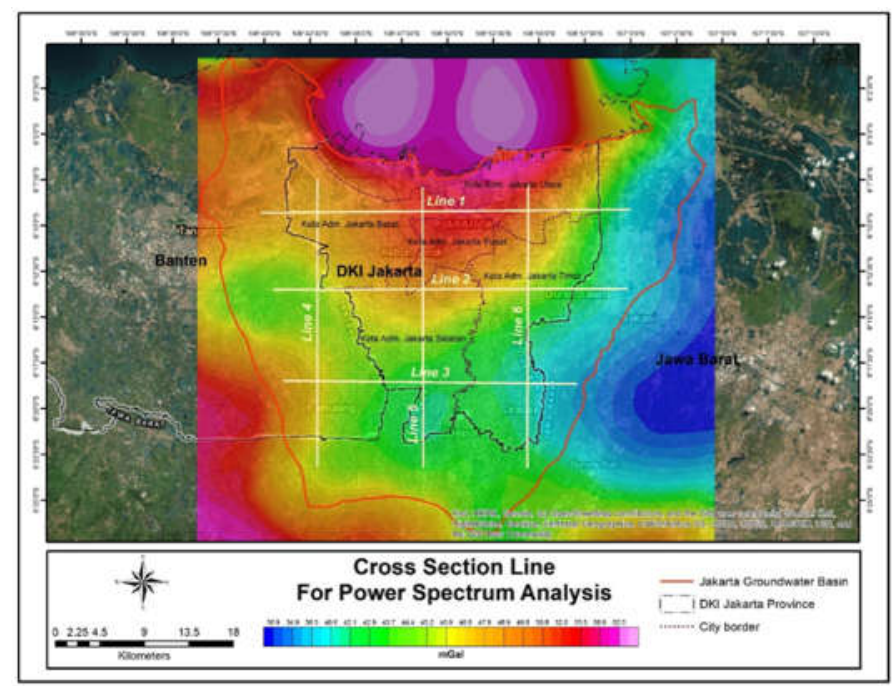

Figure 10. Six locations of cross-section lines of Bouguer gravity anomalies for Spectral Analysis 


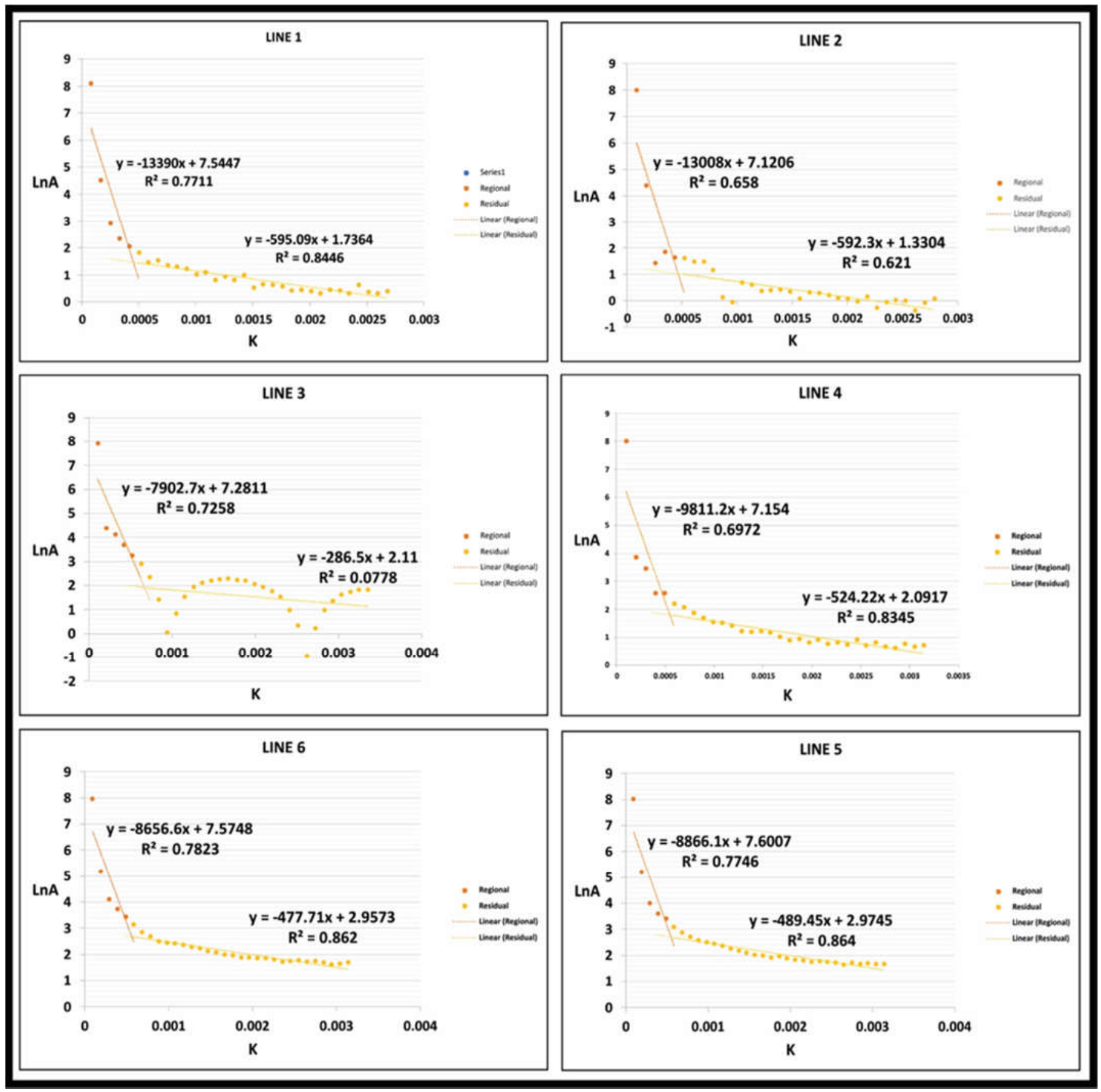

Figure 11. Spectral Analysis Result

Table 1. Depth of Regional and Residual Anomaly

\begin{tabular}{crr}
\hline Line & \multicolumn{2}{c}{ Depth } \\
\cline { 2 - 4 } & Regional $(\mathrm{m})$ & -595.09 \\
2 & -13390 & -592.3 \\
3 & -13008 & -286.5 \\
4 & -7902.7 & -524.22 \\
5 & -9811.2 & -489.45 \\
6 & -8866.1 & -477.71 \\
Average & -10272.43333 & -494.2116667 \\
\hline
\end{tabular}


Table 2. Wavelength of gravity surveys lines

\begin{tabular}{ccc}
\hline \multirow{2}{*}{ Line } & \multicolumn{2}{c}{ Depth } \\
\cline { 2 - 3 } & $\boldsymbol{k}_{\text {cutoff }}($ cycle/m) & $\lambda(\mathrm{m})$ \\
\hline 1 & $4.54 \times 10^{-04}$ & 13841.02 \\
2 & $4.66 \times 10^{-04}$ & 13472.79 \\
3 & $6.79 \times 10^{-04}$ & 9254.123 \\
4 & $5.45 \times 10^{-04}$ & 11526.74 \\
5 & $5.52 \times 10^{-04}$ & 11376.95 \\
6 & $5.65 \times 10^{-04}$ & 11129.29 \\
Average & $5.44 \times 10^{-04}$ & 11766.82 \\
\hline
\end{tabular}

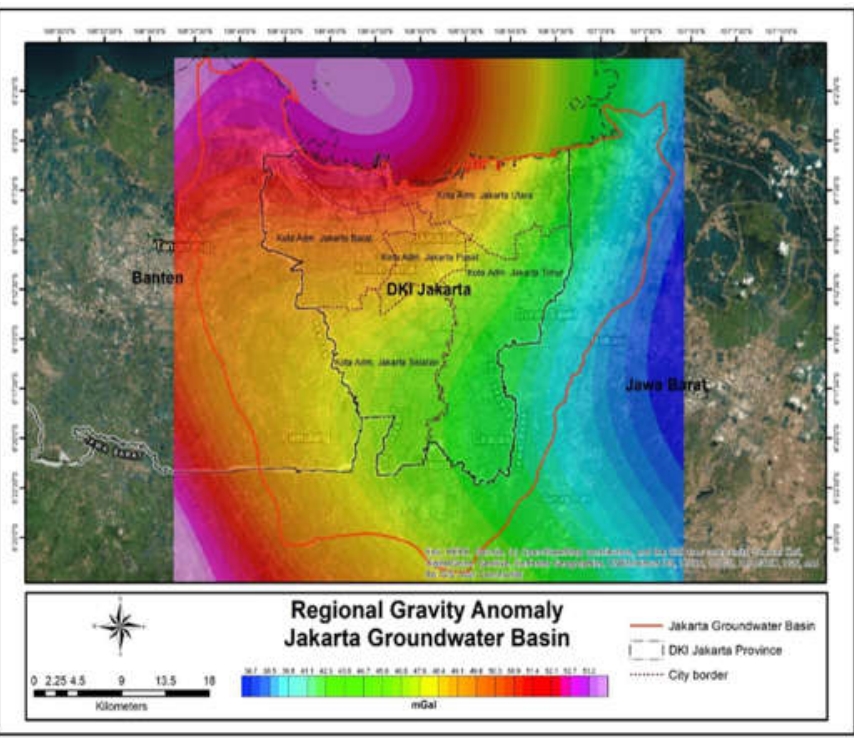

Figure 12. Regional Gravity Anomaly

is different with ranges from -7902.70 to $-13390.00 \mathrm{~m}$. Line 1 and 2 have a response to gravity anomaly with a regional depth of more than $-13,000 \mathrm{~km}$ while line 3 s.d. 6 less than $10,000 \mathrm{~m}$. the average response of gravity anomaly in the regional area is at $-10,272.43 \mathrm{~m}$, while the residual area is at $494.21 \mathrm{~m}$.

Table 2 shows the results of spectrum analysis with $\mathrm{k}$ cutoff values and Wavelength $(\lambda)$, which are used as reference parameters in the process of regional and residual anomalies separation. Line 1 has a ${ }^{\boldsymbol{k}_{\text {cutoff }}}$ value of $4.54 \times 10$ 04 cycle / $\mathrm{m}$, and the value of Wavelength $(\lambda)$ is $13841.02 \mathrm{~m}$. Line 2 has a ${ }^{k_{\text {cutoff }}}$ value of $4.66 \times 10-04$ cycle / $\mathrm{m}$, and the value of Wavelength $(\lambda)$ is $13472.79 \mathrm{~m}$. Line 3 has a ${ }^{k_{\text {cutoff }}}$ value of $6.79 \times 10-04$ cycle / $\mathrm{m}$, and the value of Wavelength $(\lambda)$ is $9254.12 \mathrm{~m}$. Line 4 has a ${ }^{\boldsymbol{k}_{\text {cutoff }}}$ value of $5.45 \times 10-04$ cycle / $\mathrm{m}$, and the value of Wavelength $(\lambda)$ is $11526.74 \mathrm{~m}$. Line 5 has a ${ }^{k_{\text {cutoff }}}$ value of $5.52 \times 10-04$ cycle / $\mathrm{m}$, and the value of Wavelength $(\lambda)$ is $11376.95 \mathrm{~m}$. Line 6 has a $\boldsymbol{k}_{\text {cutoff }}$ value of $5.65 \times 10-04$ cycle / $\mathrm{m}$, and the value of Wavelength $(\lambda)$ is $11129.29 \mathrm{~m}$. The average cutoff $\mathrm{k}$ value is a $5.44 \times 10-4$

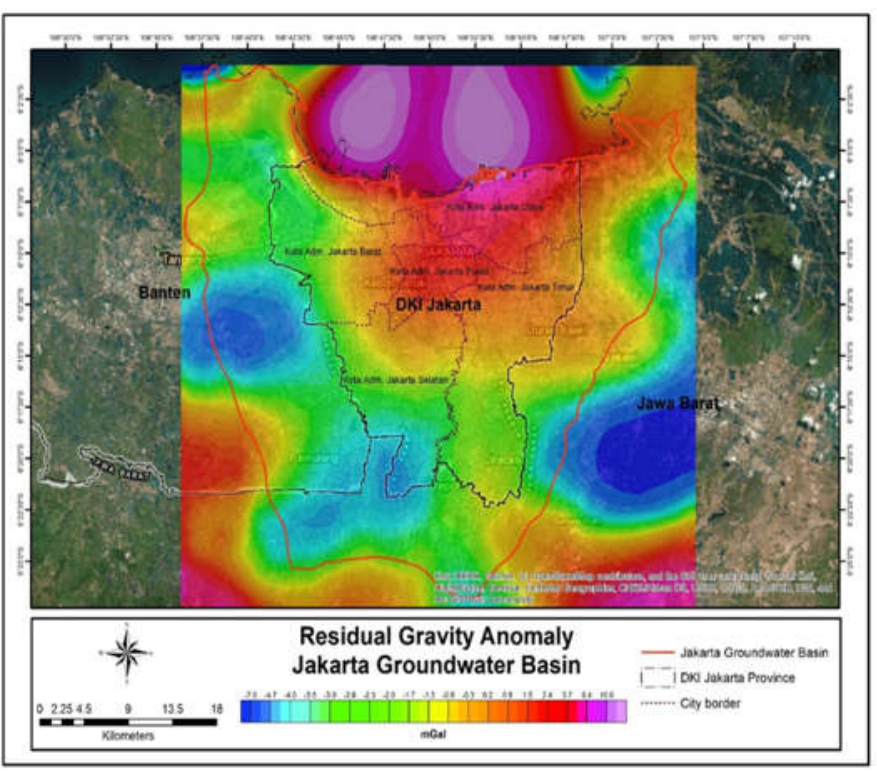

Figure 13. Residual Gravity Anomaly Maps

cycle / $\mathrm{m}$ used to calculate the average wavelength of anomaly gravity in the study area, which is equal to $11766.82 \mathrm{~m}$.

Regional anomaly values are influenced by a rock density that is at a subsurface depth. The regional gravity anomaly map (Figure. 12) shows an unusual regional response in the study area with a value from 36.7 to $53.2 \mathrm{mGal}$. It can be seen in the map that there are gradations in the distribution of gravity anomalies from high to low anomaly, which is relative from the western part of the map to the eastern part. The low anomaly distribution on the map is shown in light blue to dark blue with a value from 36.7 to $41.1 \mathrm{mGal}$. The medium anomaly distribution is in the range of values from 41.1 to $49.1 \mathrm{mGal}$ is shown in green to orange. The distribution of high anomalies is in the range value from 49.1 to $53.2 \mathrm{mGal}$ is shown in pink to light purple. Areas with high anomaly located in the northwestern part direction of Jakarta Groundwater Basin. Low anomaly areas are in the east toward the northeastern part of the Jakarta Groundwater Ba$\sin$. Areas with intermediate anomalies are relatively in the middle of the map extending from the southwestern to the northeastern part.

Complete Bouguer anomaly is a superposition between shallow anomalies and deeper anomalies. Residual gravity 
anomaly (Figure 13) is a reflection of subsurface conditions that tend to be shallower if compared to Regional gravity anomaly. In other words, the residual gravity anomaly is near-surface reflection. The residual anomaly pattern of the Jakarta groundwater basin tends to be different from its regional pattern, and this can be understood because both of them consider different depths. In the Jakarta Groundwater Basin, the distribution of residual anomaly value tends to be heterogeneous. High, medium, and low anomaly patterns can be found in almost all parts of the Jakarta Groundwater Basin. Because Residual gravity anomaly reflects nearsurface conditions, the discussion will be focused on the condition of Jakarta Groundwater Basin residual gravity. The residual values of anomalies in the study location are in the range of -7.0 - $10.0 \mathrm{mGal}$. High anomalies are shown in orange - purple with a value range of about 0.2 - $10 \mathrm{mGal}$. Low anomalies are shown in blue - light green with a value range of -7 to $-3.5 \mathrm{mGal}$. Medium anomalies are shown by dark green-yellow with a value range of -3.0 to $-1.3 \mathrm{mGal}$. High anomaly indicated by orange to light purple tends to be in the northern part of the Jakarta Groundwater Basin, this area extends to the central part of the Jakarta groundwater basin. This zone tends to be dominant along the coastline. This zone is also found in several parts of the Jakarta groundwater basin. The low anomaly zone occupies several parts of the Jakarta Groundwater Basin. Western, Southwestern and Eastern parts of Jakarta Groundwater Basin. The existence of a low anomaly zone fairly minor. The medium anomaly zone spreads almost to all parts of the Jakarta Groundwater Basin, from Northern to Southern and the Western-Eastern part of the Jakarta Groundwater Basin tends to have medium anomaly values indicated by dark green-yellow color.

According to Panjaitan (2019) based on the distribution of values, regional gravity anomaly can be divided into two anomaly groups, namely:

- Anomaly group with a gravity value of $40 \mathrm{mGal}$ up to 60 $\mathrm{mGal}$. This group shows shallow bedrocks;

- Anomaly group with a gravity value of $20 \mathrm{mGal}$ up to 40 $\mathrm{mGal}$ is thought to be a basin of sedimentary rocks and deep bedrock.

According to Panjaitan (2009), the general pattern of regional gravity anomalies in the basin area of Jakarta and surrounding areas depicts a synclinal pattern of Bekasi and Rengasdengklok-Cikampek structures with the direction of the central axis northwest-southeast. These synclinal structures are characterized by low anomaly values up to -18 $\mathrm{mGal}$, which are widely distributed to the east bordering the height of the Bambu river. High anomalies are commonly found in the west and in the north with a maximum anomaly of $60 \mathrm{mGal}$ which is spread off the coast of Tanjung Priok. The high anomaly is thought to be a basement high.

Different from Panjaitan (2009) in this study, the range of regional gravity anomalies ranges from 36.7 to $53.2 \mathrm{mGal}$. Grouping the results of Panjaitan (2009) regional gravity anomalies underwent a slight modification:

- Anomaly group with a gravity value of $45 \mathrm{mGal}$ to 53.2 $\mathrm{mGal}$. This group shows shallow bedrocks.

Gravity anomaly group $36.7 \mathrm{mGal}$ up to $45 \mathrm{mGal}$ is thought to be a sedimentary rock basin and deep bedrock.

The difference in the value of Panjaitan results (2009) and this study is probably caused by differences in the techniques of regional-residual anomaly separation and the distribution patterns of gravity data collection.

According to Panjaitan (2009), a residual anomaly is formed as a local anomaly that describes the geological structure near the surface. This anomaly forms a high and low pattern. The high pattern is interpreted as an anticline, while the low pattern is syncline. The syncline structure is to the east of Tanjung Priok, west of Bekasi and west and east of Karawang. Syncline generally forms a closed hollow contour that comes in contact with anomalous heights forming the anticline. High anomaly ( $5 \mathrm{mGal}$ ) is found in the Bekasi area to the coast of Tanjung Priok. The northern part of the heavy anti-anticline continues to offshore. Rengasdengklok Anticline is almost the same form as the Bekasi anticline; only its dimensions are different. The estimation is based on the value of Bouguer anomaly which ranges from $38 \mathrm{mGal}$ to 50 mGal. A smaller dimension anticline is found in the Tanjung Priok area with residual anomalies ranging from $0 \mathrm{mGal}$ to 4 mGal.

In this study, The residual anomaly pattern showed that in the northern part of Jakarta groundwater basin was occupied by a high anomaly pattern, The value of this high anomaly ranges from $0.2 \mathrm{mGal}$ to $10 \mathrm{mGal}$. There is a slight difference in value between the results of the study with the previous study i.e., Panjaitan (2009), this difference is likely caused by differences in filtering techniques and the distribution of the data of the two studies. In some places in the Jakarta Groundwater Basin there are several places with high anomaly values. it could be an indication of the high pattern in the research location.

According to Delinom et al. (2015) the Jakarta groundwater basin constructed by tertiary, Pleistocene, and recent rocks, consisting of sedimentary rocks, volcanic activity, and alluvial. Geologically, most materials in this basin may function as an aquifer, while the low permeability material may be categorized as an aquitard. There are three potential aquifers layers found in this basin, namely shallow aquifers, upper aquifers, and lower aquifers, which are limited by several aquitards. At present, water stored in shallow aquifers in some places has been affected by seawater intrusion, whereas in confined aquifer because it is not in direct contact with seawater, the phenomenon has not been observed.

Research conducted by Rismianto and Mak (1993) con- 


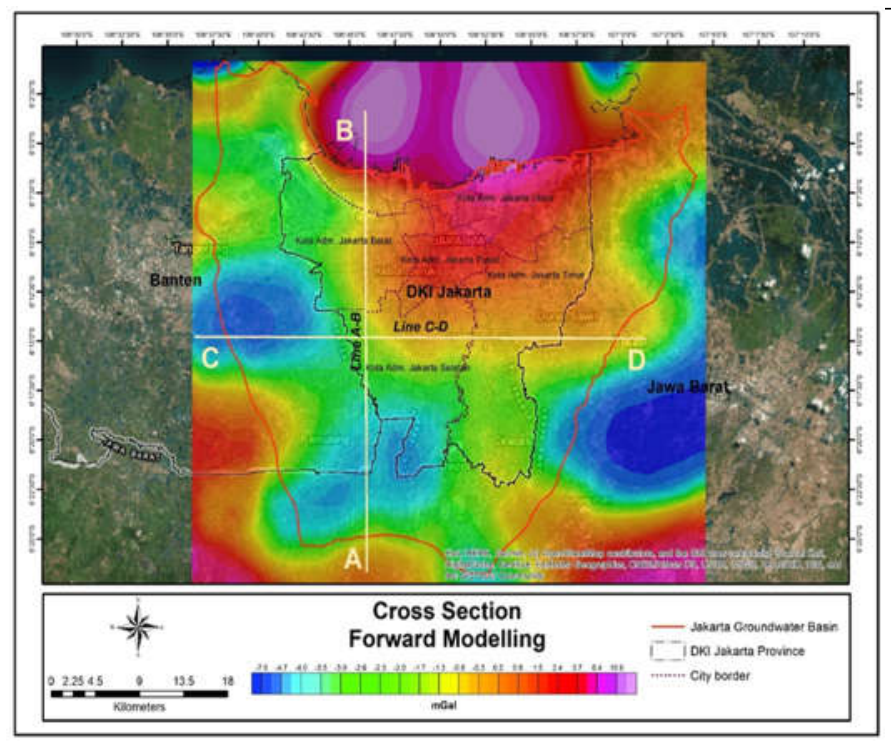

Figure 14. Cross Section Line For 2-D Modeling

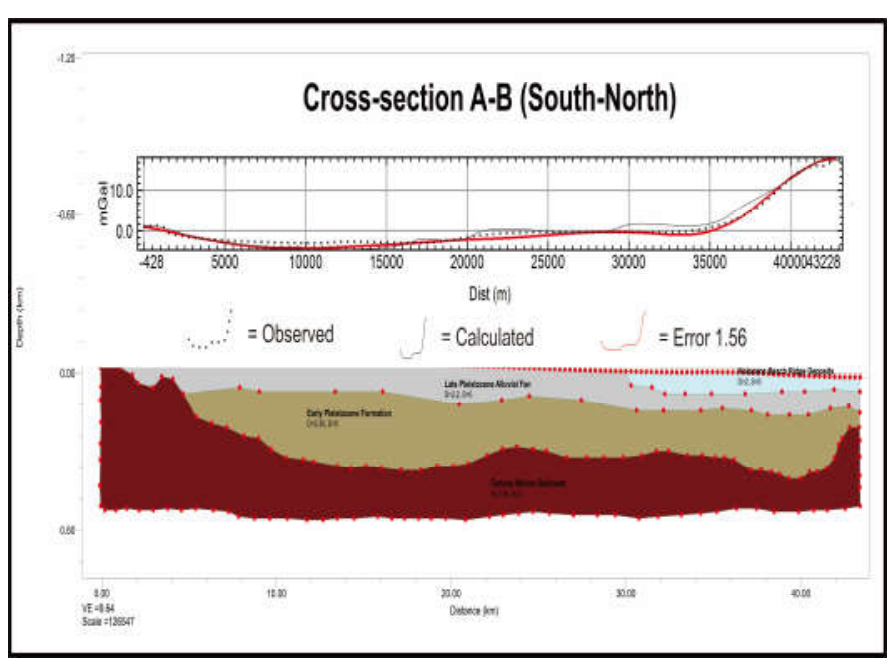

Figure 15. Cross-section A-B (South-North)

cluded that the basement of the basin were sloping lines from south to north, whereas based on the results of the study Delinom et al. (2015) showed different results, in the form of undulation of the boundary which was estimated to be affected by basins and tertiary tectonics.

Structural modeling aims to analyze the subsurface conditions and correlate with the geological cross-section. Structural modeling uses 2 cross-section lines on residual anomalies map (Figure. 14). The map used to make the 2-D model is a residual anomaly map, and the cross-section is made from South-North direction and East-West direction. Two cross-section lines are considered to represent subsurface conditions in the study area, namely the A - B cross-section line and C - D cross-section lines.

Cross-section a-b (Figure 15. Cross Section A-B (SouthNorth)) is a cross-section line across the south to the northern part of Jakarta Groundwater Basin, the length of this line is $42,800.0 \mathrm{~m}(42.8 \mathrm{~km})$. In forward modeling, there are four rock formations, namely Holocene Beach Ridge Deposits Formation, Late Pleistocene Alluvial Fan Formation, Early

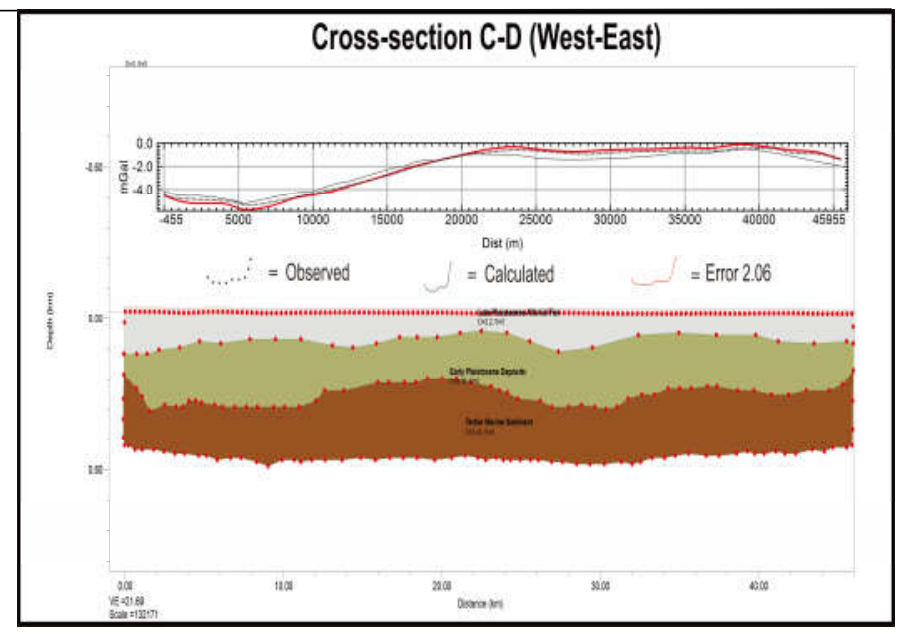

Figure 16. Cross-section C-D (West-East)

Pleistocene Rock Formation, and Tertiary Marine Sediment Formation. Holocene Beach Ridge Deposit formation, only in the northern part of the Jakarta Groundwater Basin. Based on the modeling results, the density of this formation is 2.0 $\mathrm{gr} / \mathrm{cc}$. The thickness of this formation is estimated to be around 10-20 meters. The existence of the Late Pleistocene Alluvial fan is almost all across the cross-section. In the northern part of the cross-section, this formation is under the Holocene Beach Ridge Deposit formation. Based on the results of modeling, this formation has a density of around $2.2 \mathrm{gr} / \mathrm{cc}$. The thickness of this layer ranges from 10-50 meters. Early Pleistocene Formation, has a density of $2.35 \mathrm{gr} / \mathrm{cc}$. The thickness of this formation is quite varied, and this formation is at a depth of 50-200 meters in the cross-section. The Tertiary Marine Sediment Formation is a basement of the Jakarta Groundwater Basin. The shape of the basement is undulated and tends to have a great pattern, which might be a geological structure pattern in the northern part of the cross-section. This formation has a rock density of $2.45 \mathrm{gr} / \mathrm{cc}$.

The C-D cross-section (Figure 16.) intersects the western to the eastern part of Jakarta Groundwater Basin, the length of this line is $45500 \mathrm{~m}$ (45.5 km). In forward modeling, there are three rock formations, namely Late Pleistocene Alluvial Fan Formation, Early Pleistocene Rock Formation, and Tertiary Marine Sediment Formation. The existence of the Late Pleistocene Alluvial fan is almost all across the cross-section. Based on the modeling, this formation has a density of around $2.2 \mathrm{gr} / \mathrm{cc}$. The thickness of this layer ranges from 1050 meters. Early Pleistocene Formation, has a density of 2.35 $\mathrm{gr} / \mathrm{cc}$. The thickness of this formation is quite varied, and this formation is at a depth of 50-200 meters in the cross-section. The Tertiary Marine Sediment Formation is a basement of the Jakarta Groundwater Basin. The shape of the basement is undulated and tends to have a high pattern. Based on this cross-section, the lateral eastern boundary of the Jakarta Groundwater Basin tends to still coincide with the boundary of the Groundwater Jakarta this time with the presence of this high pattern. This formation has a rock density of 2.45 gr/cc. 


\section{Conclusion}

The value of the complete Bouguer anomaly is in the range of 30.9 - $62.0 \mathrm{mGal}$. Spectral analysis of the six complete Bouguer anomaly cross-section line shows the average response of gravity anomaly in the regional area at a depth of $-10272.43 \mathrm{~m}$, while the residual area is at a depth of -494.21 $\mathrm{m}$. regional anomalies in the study area with a value range of 36.7 to $53.2 \mathrm{mGal}$, while the residual anomaly values in the study area were in the range of -7.0 - 10.0 mGal. High anomaly values are generally located in the northern part of the Jakarta Groundwater Basin. In forward modeling, there are four rock formations namely Holocene Beach Ridge Deposits Formation, Late Pleistocene Alluvial Fan Formation, Early Pleistocene Rock Formation, and Tertiary Marine Sediment Formation. Holocene Beach Ridge Deposit formation has a density of $2.0 \mathrm{gr} / \mathrm{cc}$. the thickness of this formation is estimated to be around 10-20 meters. Late Pleistocene Alluvial fan has a density of about $2.2 \mathrm{gr} / \mathrm{cc}$. the thickness of this layer ranges from 10-50 meters. Early Pleistocene Formation, has a density of $2.35 \mathrm{gr} / \mathrm{cc}$. the thickness of this formation is at a depth of 50-200 meters in the cross-section. The Tertiary Marine Sediment Formation is a basement of the Jakarta Groundwater Basin. This formation has a rock density of $2.45 \mathrm{gr} / \mathrm{cc}$.

\section{Acknowledgment}

The authors would like to thank the Padjadjaran University and Research Center for Geotechnology LIPI, which gave trust and an opportunity to write this paper. The authors also would like to express special thanks to Eko Yulianto, Ph.D., Dr.Sc. Rahmat Fajar Lubis, Dr. Ir. Haryadi Permana, Dr. Adrin Tohari, Eko Soebowo, Hendra Bakti (Research Center for Geotechnology LIPI), Adang Soewali Sadikin, Heni Rengganis, Wulan Seizarwati (Research Center for Water Resources, Ministry of Public Work and Housing), Prof. Adjat Sudrajat, Prof. Dr. Nana Sulaksana, Prof. Dr. Ildrem Syafri (Faculty of Geological Engineering, Padjadjaran University) for discussion in finishing this paper.

\section{References}

Assegaf, A. (1998). Hidrodinamika Air Tanah Alamiah Cekungan Jakarta. MSc Thesis, Geological Engineering Dept., Bandung Institute of Technology, Indonesia.

Bhattacharyya, B. K. (1978), Computer modeling in gravity and magnetic interpretation, Geophysics, 43, 912-929, doi:10.1190/1.1440873.

Carmichael, R. S., Henry, G. J., (1977). Gravity exploration for groundwater and bedrock topography in glaciated areas. Geophysics 42, 850-859.

Chandler, V. W., (1994). Gravity Investigation for Potential Groundwater Resources in Rock County, Minnesota. St. Paul.

Delinom, R. (2015). Ancaman Bawah Permukaan Jakarta: Tak Terlihat, Tak Terpikirkan, dan Tak Terduga. Jakarta:LIPI Press.

Djaja, R., Rais, J., Abidin, H. Z., And Wedyanto, K. (2004). Land
Subsidence of Jakarta Metropolitan Area. 3rd FIG Regional Conference Jakarta, Indonesia, October 3-7, 2004.

Engelen, G. B., and Kloosterman, F. H. (1996). Hydrological System Analysis, Methods, and Application. Dorddrecht: Kluwer Academic Publisher.

Fachri, M., Djuhaeni, Hutasoit, L. M., Ramdhan, A. M. (2002). Stratifrafi dan Hidrostratigrafi Cekungan Airtanah Jakarta. Bulletin Geologi (34) 3:169-189.

Han, S. S., \& Basuki, A. (2001). The Spatial Pattern of Land Values in Jakarta. Volume: 38 issue: 10, page(s): 1841-1857 Issue published: September 1, 2001.

Hinze, W. J., 2003, Bouguer reduction density - Why 2.67?: Geophysics, 68, 1559-1560.

Kagabu, M., Delinom, R. M., Lubis, R. F., Shimada, J., and Taniguchi, M. (2010.) Groundwater Characteristics In Jakarta Area, Indonesia. Riset Geologi dan Pertambangan Vol. 20 No. 2 (2010), 69 -79.

Kane, M.F.,1962. A Comprehensive System of Terrain Corrections Using a Digital Computer.Geophysics, v 27, no 4, pp. 455462

Kirsch, R., (2009). Groundwater Geophysics, 2nd ed. Springer, Berlin Heidelberg. DOI:10.1007/978-3-540-88405-7.

Kunnummal P, Anand S P, Haritha C and Rama Rao P (2017) Moho depth variations over the Maldive Ridge and adjoining Arabian \& Central Indian basin, Western Indian Ocean, from three-dimensional Inversion of Gravity anomalies; J. Asian Earth. Sci. 156 .1016/j.jseaes.2017.12.012.

Handayani, L., and Wardhana, D. D. (2017). Gravity Exploration For Groundwater And Bedrock Topography In Serang, Banten. Ris.Geo.Tam Vol. 27, No.2, December 2017 (157167) DOI: 10.14203/risetgeotam2017.v27.295.

Lubis, R. F. (2018). Urban hydrogeology in Indonesia: A highlight from Jakarta. IOP Conf. Series: Earth and Environmental Science $118 \quad$ (2018) $012022 \quad$ DOI:10.1088/17551315/118/1/012022.

Lubis, R. F., Sudaryanto, Yamano, M., Delinom, R., Miyakoshi, A., Sakura, Y., Shusaku, G., Taniguchi, M. (2009). Urban groundwater loading in Indonesian mega-cities. Trends and Sustainability of Groundwater in Highly Stressed Aquifers (Proc. of Symposium JS.2 at the Joint IAHS \& IAH Convention, Hyderabad, India, September 2009). IAHS Publ. 329, 2009.

Martodjojo, S. (1984). Evolusi Cekungan Bogor, Jawa Barat. Ph.D. Dissertation, Bandung Institute of Technology.

Murty, B. V. S., Raghavan, V. K., (2002). The gravity method in groundwater exploration in crystalline rocks区: a study in the peninsular granitic region of Hyderabad, India. Hydrogeol. J. 10, 307-321. DOI:10.1007/s10040-001-0184-2.

Nagy D.,1966. The Prism Method for Terrain Corrections Using Digital Computers. Pure Appl.Geophys. 63, 31-39.

Overmeeren, R. A. Van, (1981). A combination of electrical resistivity, seismic refraction, and gravity measurements for groundwater exploration in Sudan. Geophysics 46, 13041313.

Panjaitan, S. (2009). Aplikasi Metode Gaya Berat Untuk Identifikasi Potensi Hidrokarbon di Dalam Cekungan Jakarta dan sekitarnya. JSDG Vol 19 No.6 Desember 2009.

Rama Rao, P., K. V. Swamy, and I. V. Radhakrishna Murthy (1999), Inversion of gravity anomalies of three-dimensional density interfaces, Comput.Geosci., 25, 887-896, DOI:10.1016/ S0098-3004(99)00051-5.

Reeves, C. (2005). Aeromagnetic Surveys: Principles, Practice \& Interpretation. Canada. Geosoft Inc.

Rimbaman, R. and Suparan, P. (1999).Geomorphology, in: Coastplan Jakarta Bay Project, Coastal Environmental Geology of the Jakarta Reclamation Project and Adjacent Areas, CCOP COAST PLAN Case Study Report No. 2., Jakarta/Bangkok, 21-25, .

Rismianto, D. \& Mak, W. (1993). Environmental Aspects of Groundwater Extraction in DKI Jakarta: Changing Views. 
Proceeding of the 22nd annual convention of the Indonesian Association of Geologist, Bandung, 327-345.

Saito, M., Onodera, S., Umezawa, Y., Hosono, T., Shimizu, Y., Delinom, R.M., Lubis R. F., and Taniguchi, M. (2011). Transport And Transformation Of Chemical Components In The Groundwater Flow System Of Jakarta Metropolitan Area. Ris.Geo.Tam Vol. 21, No.2, Juni 2011 (1-139) DOI: /10.14203/risetgeotam2011.v21.41.

Sandwell, D. T., Müller, R. D., Smith, W. H. F., Garcia, E. and Francis, R. 2014. New global marine gravity model from CryoSat-2 and Jason-1 reveals buried tectonic structure. Science, Vol. 346, 6205, pp. 65-67, DOI: 10.1126/science.1258213.

Santos, F. A. M., Sultan, S. A., Sorady, A. L. El, (2006). Joint inversion of gravity and geoelectrical data for groundwater and

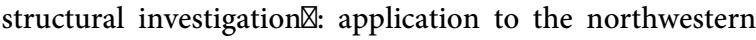
part of Sinai, Egypt. Geophys. J. Int. 165, 705-718. DOI:10. 1111/j.1365-246X. 2006. 02923. x.

Spector, A. and Grant, F.S., (1970). Statistical models for interpreting aeromagnetic data. Geophysics, Vol.35, pp. 293-302.

Tambunan, Rudy P. (2007). Dampak Perkembangan Fisik Kota terhadap Pola Tata Air Ekosistem Dataran Rendah Jakarta. Disertasi. Jenjang Doktor Program Studi Ilmu Lngkungan. Program Pascasarjana. Universitas Indonesia.

Whitehead, N., Musselman, C. (2006). Montaj Grav/Mag Interpretation User Guide and Tutorial. Canada. Geosoft Inc. 